\title{
Hydrogen sulfide formation in experimental model of acute pancreatitis*
}

\author{
Patrycja Bronowicka-Adamska1, Tomasz Hutsch², Marta Gawryś-Kopczyńska², \\ Klaudia Maksymiuk² and Maria Wróbel ${ }^{1 \otimes}$ \\ 'Chair of Medical Biochemistry, Jagiellonian University, Collegium Modicum, Kraków, Poland; ${ }^{2}$ Department of Physiology and Experimental \\ Pathophysiology, Medical University of Warsaw, Warsaw, Poland
}

\begin{abstract}
Acute pancreatitis (AP) is a disease defined as acute or chronic inflammatory process of the pancreas characterized by premature activation of digestive enzymes within the pancreatic acinar cells and causing pancreatic auto-digestion. In mammalian tissues, $\mathrm{H}_{2} \mathrm{~S}$ is synthesized endogenously from L-cysteine in regulated enzymatic pathways catalyzed by pyridoxal phosphate-dependent enzymes: cystathionine beta-synthase (CBS), gammacystathionase (CTH) and cysteine aminotransferase (CAT) coupled with 3-mercaptopyruvate sulfurtransferase (MPST). In the mitochondria, hydrogen sulfide is oxidized to sulfite, which is then converted to thiosulfate (a sulfane sulfur-containing compound) by thiosulfate sulfurtransferase (rhodanese; TST). Activity and expression of CBS, CTH, MPST, and TST have been determined in vivo in pancreas of the control rats, rats with acute pancreatitis and a sham group. Levels of low-molecular sulfur compounds, such as the reduced and oxidized glutathione, cysteine, cystine and cystathionine, were also determined. This study revealed a significant role of MPST in $\mathrm{H}_{2} \mathrm{~S}$ metabolism in the pancreas. Stress caused by the surgery (sham group) and AP cause a decrease in $\mathrm{H}_{2} \mathrm{~S}$ production associated with a decrease in MPST activity and expression. Markedly higher level of cysteine in the AP pancreas may be caused by a reduced rate of cysteine consumption in a reaction catalyzed by MPST, but it can also be a sign of proteolytic processes occurring in the changed tissue.
\end{abstract}

Key words: acute pancreatitis, cystathionine-beta-synthase, gammacystathionase, hydrogen sulfide, 3-mercaptopyruvate sulfurtransferase, rhodanese, sulfane sulfur

Received: 28 October, 2019; revised: 27 November, 2019; accepted: 06 December, 2019; available on-line: 27 December, 2019

Ðe-mail: mbwrobel@cyf-kr.edu.pl

*Acknowledgments of Financial Support:

The costs of the article published as a part of the 44th FEBS Congress Kraków 2019 - From molecules to living systems block are financed by the Ministry of Science and Higher Education of the Republic of Poland (Contract 805/P-DUN/2019).

This work was supported by a Miniatura 2.0 from the Polish National Science Center No 2018/02/X/NZ4/01170.

Abbreviations: $A P$, acute pancreatitis; $C B S$, cystathionine $\beta$-lyase; $\mathrm{CTH}, \gamma$-cystathionase; CAT, cysteine aminotransferase; MPST, 3-mercaptopyruvate sulfurtransferase; TST, rhodanese

\section{INTRODUCTION}

Acute pancreatitis (AP) is one of the most common and severe gastrointestinal diseases with poorly understood pathogenesis. AP is categorized as an inflammation with characteristic clinical features, increased blood and urine levels of the pancreatic enzymes (amylase and lipase), as well as characteristic changes in abdominal imaging. Due to the complexity of the disease, identification of etiological factors may pose a challenge in clinical practice. The most common reasons leading to the development of AP are cholelithiasis and alcohol abuse (Konończuk et al., 2018).

Hydrogen sulfide $\left(\mathrm{H}_{2} \mathrm{~S}\right)$ plays an important role in AP pathogenesis. $\mathrm{H}_{2} \mathrm{~S}$ acts as an important mediator of inflammation. What is more - cystathionase $(\mathrm{CTH})$ is the main enzyme involved in $\mathrm{H}_{2} \mathrm{~S}$ formation in the pancreas (Qu et al., 2014). $\mathrm{H}_{2} \mathrm{~S}$ 's lipophilic character allows its penetration into cells without transporters. It is produced endogenously in the liver, kidneys, pancreas, brain and many other human and mammalian tissues. Its synthesis involves the PLP dependent participation of enzymes: cystathionine beta-synthase (CBS, EC 4.2.1.22), gamma-cystathionase (CTH, EC 4.4.1.1) and zinc ionsdependent 3-mercaptopyruvate sulfurtransferase (MPST, EC 2.8.1.2). $\mathrm{H}_{2} \mathrm{~S}$ can be produced enzymatically from L-cysteine, L-cystine, 3-mercaptopyruvate, L-homocysteine and D-cysteine. The synthesis of $\mathrm{H}_{2} \mathrm{~S}$ from $\mathrm{D}$ cysteine takes place with participation of $\mathrm{D}$-amino acid oxidase (DAO) and MPST. $\mathrm{H}_{2} \mathrm{~S}$ can be also released non-enzymatically from persulfates under reducing conditions. The major oxidation products of $\mathrm{H}_{2} \mathrm{~S}$ are thiosulfate and sulfate. This process occurs in the mitochondria (Stipanuk \& Ueki 2011). The sulfide oxidation pathway begins with the sulfide quinone oxidoreductase (SQR) and includes a sulfur dioxygenase (SDO), rhodanese; (TST, EC 2.8.1.1) and a sulfite oxidase (Stein \& Bailey 2013, Libiad et al., 2014) (Scheme 1).

$\mathrm{H}_{2} \mathrm{~S}$ inhibits insulin secretion through interactions with the $K_{\text {ATP }}$ channels in pancreatic islet cells, and thus plays an important role in regulation of this process. An increase in the blood glucose level stimulates production and accumulation of ATP in the cell. $K_{\text {ATP }}$ channels are blocked, followed by opening of the voltage-dependent calcium channels and $\mathrm{Ca}^{2+}$ ion influx, resulting in insulin secretion. $\mathrm{H}_{2} \mathrm{~S}$-mediated/dependent activation of $K_{\text {ATP }}$ channels prevents membrane depolarization and insulin secretion. High glucose blood level inhibits $\mathrm{H}_{2} \mathrm{~S}$ production through the pancreatic islets and causes secretion of insulin (Yang et al., 2005).

This study was conducted to investigate the role of enzymes involved in the hydrogen sulfide metabolism, especially the role of MPST and TST in pathogenesis of AP. It could also contribute to recent scientific reports regarding the effect of $\mathrm{H}_{2} \mathrm{~S}$ on apoptosis of pancreatic islet beta cells and inflammation exacerbation. The same reports had shown the protecting effect of $\mathrm{H}_{2} \mathrm{~S}$ upon minor cell damage in pancreatic model. Various studies had shown anti-inflammatory, immunomodulatory, anti- 


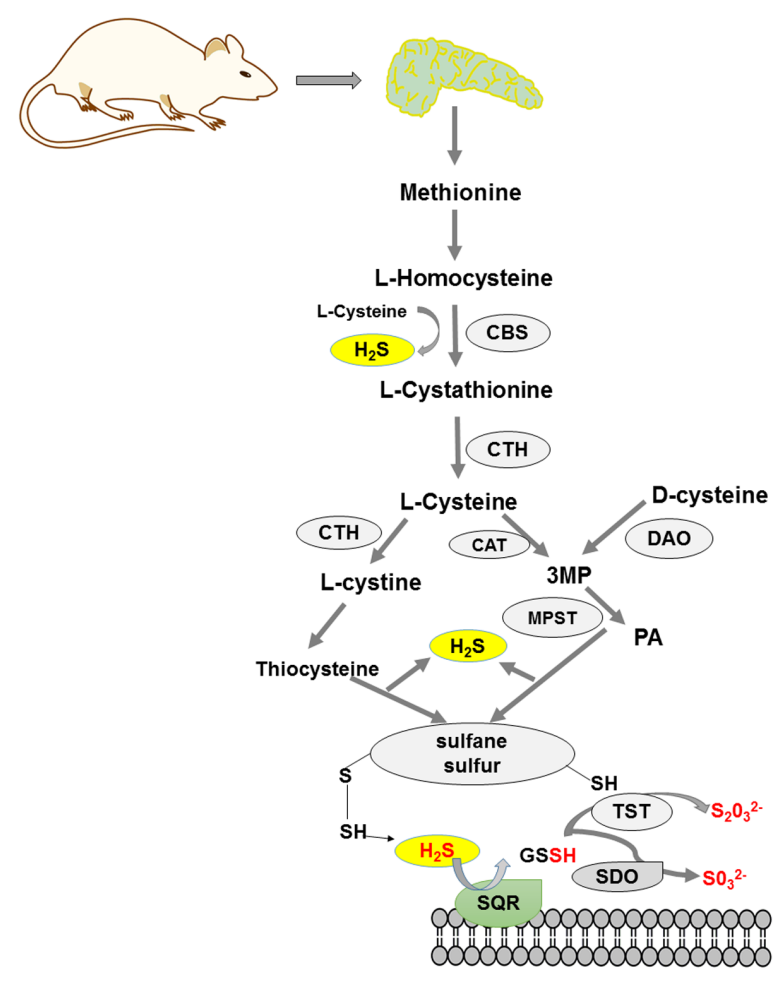

Scheme 1. $\mathrm{H}_{2} \mathrm{~S}$ metabolism in the mammalian pancreas

The scheme is based on Wróbel et al., 2012, and Libiad et al., 2014. CAT, cysteine aminotransferase; CBS, cystathionine $\beta$-lyase; CTH, $\gamma$-cystathionase; GSSG, glutathione oxidized form; DAO, Damino acids oxidase; MPST, 3-mercaptopyruvate sulfurtransferase; $3 \mathrm{MP}$, 3-mercaptopyruvate; $\mathrm{PA}$, pyruvate; $\mathrm{SQR}$, sulfide quinone oxidoreductase; SDO, sulfur dioxygenase; TST, rhodanese

apoptotic and cytoprotective effects of hydrogen sulfide. Moreover, its inhibitory effect on fibrosis was confirmed (Zanardo et al., 2006; Elrod et al., 2007; Murphy \& Steenbergen, 2007; Kang et al., 2009; Sodha et al., 2009; Kimura et al., 2010; Kabil et al., 2011). The results of this study are an important premise about a possible role of $\mathrm{H}_{2} \mathrm{~S}$ in the pathogenesis of acute pancreatitis, in which inflammation and fibrosis of the pancreatic parenchyma are the most important pathological processes.

\section{MATERIALS AND METHODS}

Chemicals. Trizol, ethidium bromide and EDTA-disodium salt dihydrate were obtained from Lab - Empire S.A (Rzeszow, Poland). Reverse Transcriptase M-MuLV was obtained from Promega Poland (Warszawa, Poland). Polymerase DNA Dream Taq ${ }^{\mathrm{TM}}$, Gene Ruler 100 bp DNA Ladder, Oligo (DT) 18 primer, and dNTP Mix were obtained from Thermo Scientific (Warszawa, Poland). L-Glutathione reduced (GSH), L-cysteine, cystathionine (CTN), DL-homoserine (HSer), 1-fluoro-2,4-dinitrobenzene (DNFB), bathophenanthroline-disulfonic acid disodium salt (BPDS), acetonitrile, pyridoxal phosphate (PLP), $\beta$-Nicotinamide adenine dinucleotide reduced disodium salt hydrate (NADH), L-Lactic dehydrogenase (LDH), 3-mercaptopyruvate acid sodium salt, D,L-dithiothreitol, (DTT), N-ethylmaleimide (NEM), DL-propargylglycine (PPG), sodium dihydrogen phosphate dihydrate pure, sodium sulfite, chloroform, isopropanol, agarose, sodium hydrosulfide hydrate, sodium chloride, Folin-Ciocalteu's phenol reagent, iron (III) nitrate no- nahydrate, sodium thiosulfate pentahydrate, sodium carbonate, and N,N-dimethyl-p-phenylenediamine sulfate salt were obtained from Sigma-Aldrich (Poznan, Poland). $N^{\varepsilon}$-methyllysine was obtained from Bachem (Bubendorf, Switzerland). Trifluoroacetic acid (TFA), and 2-mercaptoethanol were purchased from Fluka Chemie $\mathrm{GmbH}$ (Buchs, Switzerland). Ethanol and 70\% perchloric acid (PCA), 38\% formaldehyde, 65\% nitric acid, 38\% hydrochloric acid, ammonia solution $25 \%$ pure, sodium potassium tarate, copper sulphate pentahydrate, potassium dihydrogen phosphate, ferric chloride, zinc acetate dehydrate pure, and sodium hydroxide were from Polskie Odczynniki Chemiczne S.A. (Gliwice, Poland). Potassium cyanide was from Merck Sp. z o.o. (Warszawa, Poland).

Experimental procedures. Surgical procedure. This study was carried out on an in vivo rat model. The experiment involved 33 male (7-8 weeks) Wistar Kyoto rats (Central Laboratory of Experimental Animals, Medical University of Warsaw) weighing 220-320 g, receiving a standard diet and water ad libitum in a varied environment (e.g. cellulose tunnels). Rats were housed in animal cages at $22^{\circ} \mathrm{C}\left( \pm 2^{\circ} \mathrm{C}\right), 55 \%\left( \pm 5^{\circ} \mathrm{C}\right)$ humidity and were divided into three groups. The light cycle was set as follows: 12 hours light/12 hours dark. The ventilation system provided 20 air changes per hour indoors. The animals were separated after the surgery and located in different cages to protect the postoperative wounds. Anesthesia, surgery, blood sampling, tissues collection and animal euthanasia were carried out in the operating room of the Department of Physiology and Experimental Pathophysiology at the Medical University in Warsaw. All experiments were approved by the II Local Ethics Committee for Animal Experiments (Application No.WAW2/216/2018, September 17, 2018).

Experimental group. Animals were divided into three experimental groups.

Control group (11 animals): no surgery was performed on the rats. Sham group (11 animals): a sham surgical induction of acute pancreatitis was performed in rats. This procedure allowed to assess the impact of the surgery, anesthesia and analgesia on the course of the experiment. Experimental group ( $\mathrm{AP}=$ acute pancreatitis) (11 animals): AP was induced in rats by surgical ligation of the bile pancreatic duct. After the procedure, the rats had a stagnant pancreatic juice in the pancreatic ducts and an intra-pancreatic enzyme activation.

24 hours after surgery, the blood was drawn from the animals, and then the animals were put into deep anesthesia by administering a lethal dose of xylazine and ketamine, followed by vertebral dislocation. Subsequently, a section was performed to collect the tissues, including the pancreas for biochemical, molecular and histopathological tests.

Tissue homogenates. In order to determine the activity of enzymes (MPST, CTH, CBS, TST) and the level of sulfane sulfur and protein, pancreas were weighed and homogenized in ice-cold $0.1 \mathrm{M}$ phosphate buffer, $\mathrm{pH} 7.5(1 \mathrm{~g} / 4 \mathrm{~mL})$, for $1 \mathrm{~min}$ at $8000-9500 \mathrm{rpm}$ using a blender homogenizer. The homogenates were centrifuged at $1600 \times g$ for $10 \mathrm{~min}$. After centrifugation, the supernatants were used to determine enzymatic activity (CTH, MPST, CBS and TST), the level of sulfane sulfur, and protein content.

For the RP-HPLC method, the tissues were weighed and homogenized at 8000-9500 rpm in ice-cold $10 \%$ PCA $/ 1 \mathrm{mM}$ BPDS ( $1 \mathrm{~g} / 3 \mathrm{ml})(1 \mathrm{~g}$ tissue $/ 3 \mathrm{ml}$ solution). The homogenates were centrifuged for $10 \mathrm{~min}$ at $4^{\circ} \mathrm{C}$, 
$1400 \times g$. The supernatants were either immediately used for assays or stored at $-80^{\circ} \mathrm{C}$ until HPLC analysis.

Histopathological evaluation. Tissue sections of the pancreas, fixed in $10 \%$ buffered formalin, were dehydrated using graded ethanol and xylene baths, and embedded in paraffin wax. Sections of 3-4 $\mu \mathrm{m}$ were stained with haematoxylin and eosin (HE). General histopathological examination was carried out at magnification of $10 \times$, $40 \times$ and $100 \times$ (objective lens) and $10 \times$ (eyepiece), and photographic documentation was made. Micrographs were taken at the magnification of $10 \times$ (objective lens) and 10× (eyepiece), using a standard light microscope Olympus BX41 and CellSens software (Olympus Corporation, Tokyo, Japan).

Amylase, lipase estimation. Serum amylase and lipase activities were assessed by a commercial laboratory, LAB WET (Kraków, Poland). The enzyme activity was expressed as units of enzyme per liter.

Expression of MPST, CTH, CBS, TST in tissue homogenates. RNA extraction, cDNA synthesis and RT-PCR analysis. Total RNA was extracted from the rat pancreas using TRIZOL solution and later used to synthesize cDNA. The temperature profile of RT-PCR amplification and primer sequences for the MPST, CTH, CBS, TST and Glyceraldehyde-3-phosphate dehydrogenase $(\mathrm{GAPDH})$ genes are presented in Table 1. GAP$\mathrm{DH}$ was used as a normalization control. The PCR reaction products were separated electrophoretically in a $2.5 \%$ agarose gel and visualized with ethidium bromide under UV light, and photographed using ChemiDoc ${ }^{\mathrm{TM}}$ MP Imaging System (Bio-Rad). The band intensity was semiquantified by densitometry using a gel analysis software, UVI-KS 4000i/ImagePC (Syngen Biotech, Poland), employing Glyceraldehyde-3-phosphate dehydrogenase as a marker gene.

Enzymes' assay (MPST, CTH, CBS, and TST) in the pancreatic homogenates. MPST activity was assayed according to the method of Valentine and Frankelfeld (Valentine \& Frankelfeld, 1974), following a procedure described in our previous paper (Wróbel et al., 2004; Bronowicka-Adamska et al., 2015). The enzyme activity was expressed as nmoles of pyruvate produced during $1 \mathrm{~min}$ incubation at $37^{\circ} \mathrm{C}$ per $1 \mathrm{mg}$ of protein. CTH activity was determined using the Matsuo \& Greenberg's method (Greenberg, 1958) with modifications described by Czubak and others (Czubak et al.,
2002). The difference between the initial value of absorbance (before LDH addition) and the lowest value (after $\mathrm{LDH}$ addition) corresponded to the amount of alphaketobutyrate formed in the course of the cystathionase reaction. Cystathionase activity was expressed as nmoles of alpha-ketobutyrate formed during $1 \mathrm{~min}$ incubation at $37^{\circ} \mathrm{C}$ per $1 \mathrm{mg}$ of protein.

The activity of CBS was examined in tissue homogenate in the presence of DL-homoserine as a substrate, after 15 minutes incubation at $37^{\circ} \mathrm{C}$, according to the protocol described in Bronowicka-Adamska and others (Bronowicka-Adamska et al., 2015). The CBS activity was expressed as pmoles of cystathionine formed during $1 \mathrm{~min}$ incubation at $37^{\circ} \mathrm{C}$ per $1 \mathrm{mg}$ of protein.

TST activity was assayed in the tissue homogenates according to Sörbo (Sörbo, 1955), with modifications described by Bronowicka-Adamska and others (Bronowicka-Adamska et al., 2017). The enzyme units were defined as nmoles of $\mathrm{SCN}^{-}$generated per minute per $1 \mathrm{mg}$ of protein at $20^{\circ} \mathrm{C}$ under the prescribed assay conditions.

Sulfane sulfur and protein level. The sulfane sulfur level was determined by the Wood (Wood, 1987) method, based on cold cyanolysis and colorimetric detection of ferric thiocyanate complex ion. The sulfane sulfur level was expressed as nmoles of $\mathrm{SCN}^{-}$produced per $1 \mathrm{mg}$ of protein.

Protein concentration was determined by the method of Lowry and others (Lowry et al., 1951) using crystalline bovine serum albumin as a standard.

Detection of $\mathrm{H}_{2} \mathrm{~S}$ production in tissue homogenates. Pancreas $\mathrm{H}_{2} \mathrm{~S}$-production was determined essentially as described in previous studies (Stipanuk \& Beck, 1982; Collin et al., 2005). Pancreas tissue was homogenized in $100 \mathrm{mM}$ ice-cold potassium phosphate buffer $(\mathrm{pH} 7.4)(1: 10, \mathrm{w} / \mathrm{v})$. The reaction mixture (total volume, $500 \mu \mathrm{l})$ contained $20 \mu \mathrm{l} 10 \mathrm{mM}$ L-cysteine, $20 \mu \mathrm{l} 2 \mathrm{mM}$ pyridoxal 5-phosphate, $30 \mu \mathrm{l} 0.9 \% \mathrm{NaCl}$ and $430 \mu \mathrm{l}$ tissue homogenate. The reaction was performed in eppendorf tubes and initiated by transferring the tubes from ice to a water bath at $37^{\circ} \mathrm{C}$. The enzymatic reaction was immediately stopped by the addition of $250 \mu \mathrm{l} 10 \%$ trichloroacetic acid in order to denature proteins. After incubation for $30 \mathrm{~min}, 250 \mu \mathrm{l} 1 \% \mathrm{zinc}$ acetate was added to trap the evolved $\mathrm{H}_{2} \mathrm{~S}$, followed by $10 \%$ trichloroacetic acid. Subsequently, $133 \mu \mathrm{l}$ of $20 \mathrm{mM}$ $\mathrm{N}, \mathrm{N}$-dimethyl-p-phenylenediamine sulfate in $7.2 \mathrm{M} \mathrm{HCl}$,

Table 1. RT-PCR conditions: primer sequences, annealing temperatures, and gene fragment sizes

\begin{tabular}{|c|c|c|c|c|c|c|c|c|c|}
\hline \multirow{2}{*}{ Gene } & \multirow{2}{*}{ Primer } & \multirow{2}{*}{$\begin{array}{l}\text { Product } \\
\text { size } \\
\text { (bp) }\end{array}$} & \multicolumn{7}{|c|}{ PCR conditions } \\
\hline & & & $\begin{array}{l}\text { Predena- } \\
\text { turation }\end{array}$ & $\begin{array}{l}\text { Denatu- } \\
\text { ration }\end{array}$ & $\begin{array}{l}\text { Anne- } \\
\text { aling }\end{array}$ & $\begin{array}{l}\text { Elon- } \\
\text { gation }\end{array}$ & $\begin{array}{l}\text { Exten- } \\
\text { sion }\end{array}$ & $\begin{array}{l}\text { Cyc- } \\
\text { les }\end{array}$ & References \\
\hline MPST & $\begin{array}{l}\text { F: 5'TCCTGGGTGGAGTGGTACAT3' } \\
\text { R: 5'GTGAAACAAGCTAGGTGGGC3' }\end{array}$ & $339 \mathrm{bp}$ & $\begin{array}{l}94^{\circ} \mathrm{C} \\
5 \mathrm{~min}\end{array}$ & $\begin{array}{l}95^{\circ} \mathrm{C} \\
30 \mathrm{~s}\end{array}$ & $\begin{array}{l}54^{\circ} \mathrm{C} \\
30 \mathrm{~s}\end{array}$ & $\begin{array}{l}72^{\circ} \mathrm{C} \\
1 \mathrm{~min}\end{array}$ & $\begin{array}{l}72^{\circ} \mathrm{C} \\
8 \mathrm{~min}\end{array}$ & 28 & $\begin{array}{l}\text { Bronowicka- } \\
\text {-Adamska et al., } \\
2017\end{array}$ \\
\hline CBS & $\begin{array}{l}\text { F: 5'GAGCGAGCCGGAACCTTGAAGC3' } \\
\text { R: 5'CACCTATCCACCACCGCCCTGTC3' }\end{array}$ & $579 \mathrm{bp}$ & $\begin{array}{l}94^{\circ} \mathrm{C} \\
5 \mathrm{~min}\end{array}$ & $\begin{array}{l}95^{\circ} \mathrm{C} \\
30 \mathrm{~s}\end{array}$ & $\begin{array}{l}62.2^{\circ} \mathrm{C} \\
1 \mathrm{~min}\end{array}$ & $\begin{array}{l}72^{\circ} \mathrm{C} \\
1 \mathrm{~min}\end{array}$ & $\begin{array}{l}72^{\circ} \mathrm{C} \\
5 \mathrm{~min}\end{array}$ & 28 & $\begin{array}{l}\text { Collin et al., } \\
2005\end{array}$ \\
\hline CTH & $\begin{array}{l}\text { F: 5'TTTGTATACAGCCGCTCTGGA3' } \\
\text { R: 5'ACAAGCTTGGTCTGTGGTGT3' }\end{array}$ & $290 \mathrm{bp}$ & $\begin{array}{l}94^{\circ} \mathrm{C} \\
5 \mathrm{~min}\end{array}$ & $\begin{array}{l}95^{\circ} \mathrm{C} \\
30 \mathrm{~s}\end{array}$ & $\begin{array}{l}56^{\circ} \mathrm{C} \\
30 \mathrm{~s}\end{array}$ & $\begin{array}{l}72^{\circ} \mathrm{C} \\
2 \mathrm{~min}\end{array}$ & $\begin{array}{l}72^{\circ} \mathrm{C} \\
8 \mathrm{~min}\end{array}$ & 36 & $\begin{array}{l}\text { Bronowicka- } \\
\text {-Adamska et al., } \\
2017\end{array}$ \\
\hline TST & $\begin{array}{l}\text { F: 5'CTCTATCGAGCCGCTGGTCTC3' } \\
\text { R: 5'TCGTAAGGCGAAGTCGTGTC3' }\end{array}$ & $200 \mathrm{bp}$ & $\begin{array}{l}94^{\circ} \mathrm{C} \\
5 \mathrm{~min}\end{array}$ & $\begin{array}{l}94^{\circ} \mathrm{C} \\
30 \mathrm{~s}\end{array}$ & $\begin{array}{l}55.6^{\circ} \mathrm{C} \\
30 \mathrm{~s}\end{array}$ & $\begin{array}{l}72^{\circ} \mathrm{C} \\
2 \mathrm{~min}\end{array}$ & $\begin{array}{l}72^{\circ} \mathrm{C} \\
8 \mathrm{~min}\end{array}$ & 38 & $\begin{array}{l}\text { Bronowicka- } \\
\text {-Adamska et al., } \\
2017\end{array}$ \\
\hline GAPDH & $\begin{array}{l}\text { F: 5'CCGCATCTTCTTGTGCAGTG3' } \\
\text { R: 5'ACCAGCTTCCCATTCTCAGC3' }\end{array}$ & $239 \mathrm{bp}$ & $\begin{array}{l}94^{\circ} \mathrm{C} \\
5 \mathrm{~min}\end{array}$ & $\begin{array}{l}95^{\circ} \mathrm{C} \\
30 \mathrm{~s}\end{array}$ & $\begin{array}{l}54^{\circ} \mathrm{C} \\
30 \mathrm{~s}\end{array}$ & $\begin{array}{l}72^{\circ} \mathrm{C} \\
1 \mathrm{~min}\end{array}$ & $\begin{array}{l}72^{\circ} \mathrm{C} \\
8 \mathrm{~min}\end{array}$ & 28 & $\begin{array}{l}\text { NCBI Primer } \\
\text { Blast }\end{array}$ \\
\hline
\end{tabular}



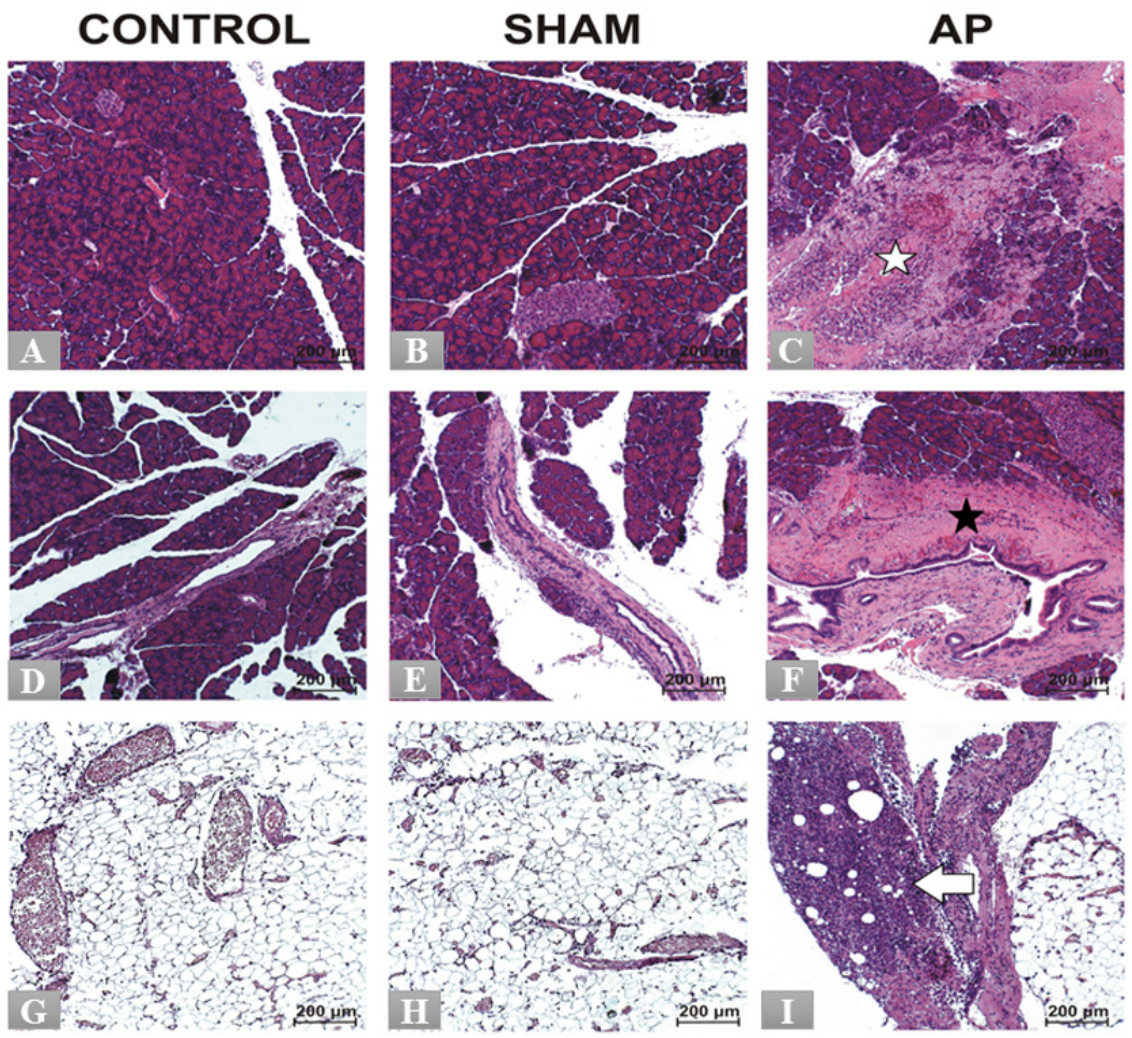

Figure 1. Histopathological picture of the pancreas and mesentherium after hematoxylin-eosin staining at a magnification of $x 10$ (lens)

A, B, C, Parenchyma of the pancreas; D, E, F, Pancreatic ducts; G, H, I, Fat tissue of the mesentherium. White star - extensive focal coagulation necrosis and mixed inflammatory infiltrate in the pancreatic parenchyma; Black star - peridural necrosis and inflammatory infiltrates; White arrow - focus of fat necrosis with inflammatory infiltrates.

and $133 \mu \mathrm{l}$ of $30 \mathrm{mM} \mathrm{FeCl}_{3}$ in $1.2 \mathrm{M} \mathrm{HCl}$ were added, and the absorbance of the resulting solution $(670 \mathrm{~nm})$ was measured 15 min thereafter, using a 96-well microplate reader (BioTEK EPOCH2). Incubation mixture to which trichloroacetic acid was added at time zero prior to the addition of cysteine, was used to determine the basal concentration of $\mathrm{H}_{2} \mathrm{~S}$. The standard curve was linear at a concentration range of $3.25-250 \mu \mathrm{M}$ with a correlation coefficient of 0.993 . Results were expressed as nmol of $\mathrm{H}_{2} \mathrm{~S}$ produced during 30 minute incubation at $37^{\circ} \mathrm{C}$ per $1 \mathrm{mg}$ of protein.

RP-HPLC (Reverse Phase High Performance Liquid Chromatography). The levels of cystathionine, the reduced (GSH) and oxidized (GSSG) glutathione, cysteine (CSH), and cystine (CSSC) in the incubation mixtures were determined using the RP-HPLC method of Dominik and others (Dominik et al., 2001) with modifications (Bronowicka-Adamska et al., 2011; BronowickaAdamska et al., 2015).

Statistical analysis. All results were expressed as means \pm S.E.M. Significance of the differences between controls and investigated values were calculated using the Mann-Whitney test $(p<0.05)$. Each experiment was repeated at least three times.

\section{RESULTS AND DISCUSSION}

Experiments were carried out on rat pancreas in the three groups: control, sham and experimental. There were no significant changes in the histopathological picture between the control and sham group (Fig. 1), but there were changes in the investigated biochemical parameters (Table 3). Significant changes were observed in the experimental group (acute pancreatitis). Mixed inflammatory infiltration with neutrophil dominance, coagulation necrosis, fibrinous exudate and interstitial hemorrhage in the pancreas parenchyma were observed. Moreover, periductal and perilobular foci of necrosis with fibrinous exudate were found. In the mesentherium, fat necrosis with inflammatory infiltrates occurred. The changes described may qualify as acute hemorrhagic pancreatitis (Fig. 1).

We determined a significantly higher $(p<0.05)$ amylase and lipase activity in the serum of rats from the experimental group (acute pancreatitis) in comparison to the control and sham groups (Table 2). Serum amylase level was used (Batra et al., 2015) only to confirm that the bile pancreatic duct ligation was performed correctly and acute pancreatitis was induced (Hyun \& Lee 2014).

Table 2. The activity of amylase and lipase

\begin{tabular}{lll}
\hline & Serum Amylase & Serum Lipase \\
\hline \multicolumn{1}{c}{ U/I } \\
\hline CONTROL & $718 \pm 71$ & $8 \pm 1$ \\
\hline SHAM & $411 \pm 47^{*}$ & $10 \pm 1$ \\
\hdashline AP & $8070 \pm 2186^{* \Delta}$ & $161 \pm 64^{* \Delta}$ \\
\hline
\end{tabular}

Data is presented as mean values representing the average of four to five determinations in three experimental groups. Statistical analysis was performed using the Mann-Whitney test $\left({ }^{*} p<0.05\right)$. Values in Table 1 are summarized as the mean \pm standard deviation of the mean. $\mathrm{AP}=$ acute pancreatitis, ${ }^{*} p<0.05 \mathrm{SHAM}, \mathrm{AP}$ vs. CONTROL, ${ }^{\Delta} p<0.05$ AP vs. SHAM 


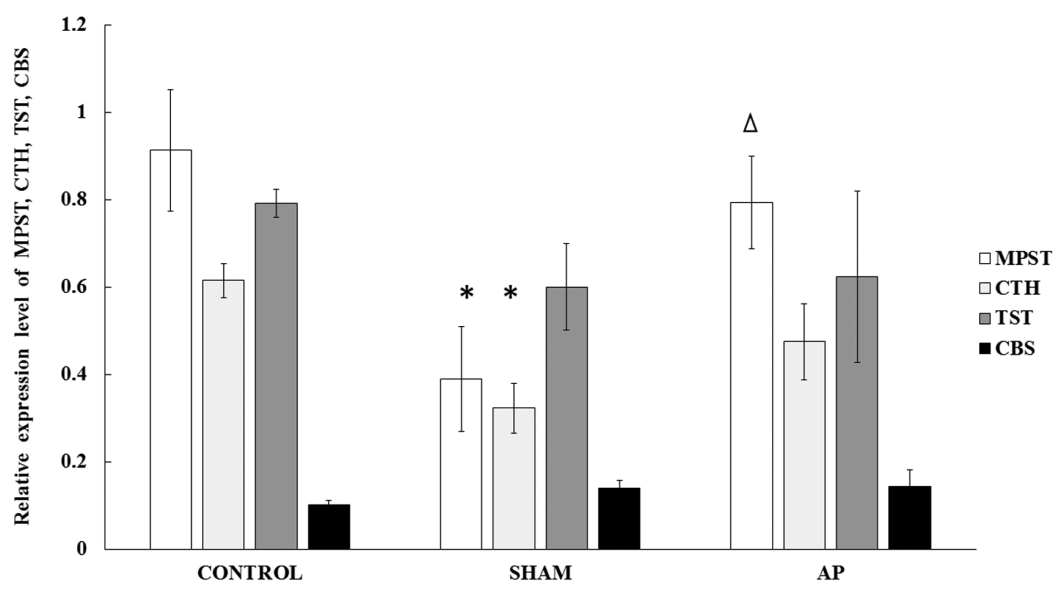

Figure 2. The relative expression level of MPST, CTH, TST, and CBS

Relative expression level of MPST, CTH, TST, and CBS in the experimental groups, bands were normalized using GAPDH, the mean of which was taken as equal to one. AP=acute pancreatitis, ${ }^{*} p<0.05 \mathrm{SHAM}, \mathrm{AP}$ vs. CONTROL, ${ }^{\Delta} p<0.05$ AP vs. SHAM, Mann-Whitney test

Figure 2 and Table 3 show the expression and activity of four enzymes involved in $\mathrm{H}_{2} \mathrm{~S}$ metabolism (Scheme 1). Our studies confirmed expression (mRNA levels) of MPST, CTH, TST and CBS in the normal rat pancreas (control group). In the sham group, MPST, $\mathrm{CTH}$ and TST expression was lower in comparison to the control group. For MPST and CTH, the change was statistically significant $(\phi<0.05)$. In acute pancreatitis, expression of MPST, CTH, and TST was also lower in comparison to the control pancreas, but these changes were not statistically significant. On the other hand, low CBS expression found in all three experimental groups did not change. A significant decrease in the enzyme expression (especially MPST, CTH) in the sham group, when compared to the control group, could be explained by the stress caused by the surgery, anesthesia and analgesia. The only one significant change between the sham group and acute pancreatitis group was an increase in MPST expression, and it could be coupled with the inflammatory changes in the pancreas.

The highest specific activity, expressed in nmol of product produced during $1 \mathrm{~min}$ per $1 \mathrm{mg}$ of protein, was determined for TST and MPST, yielding 2056 \pm 660 and $1735 \pm 430$, respectively. Activity of CBS was not detectable in the control and acute pancreatitis groups, which is in accordance with its low expression (Table 3). A two-fold decrease in TST and CTH activity, and a four-fold decrease in MPST activity in acute pancreatitis was determined in comparison to the control group.
Nagahara (Nagahara, 2018), confirmed that MPST is a housekeeping and multifunctional enzyme, and its activity is regulated by the redox change. MPST was also inhibited under oxidizing conditions, resulting in suppression of cysteine degradation. The sulfane sulfur level, in turn, determined in all of the examined groups, remained stable in the range of $166 \pm 50$ to $185 \pm 50 \mathrm{nmol}$ per $1 \mathrm{mg}$ of protein (Table 3 ).

The ability for hydrogen sulfide formation in the normal rat pancreas was confirmed. It was 5.5 times lower in the sham group and fell to a non-detectable level in the acute pancreatitis group (Fig. 3). The $\mathrm{H}_{2} \mathrm{~S}$ production was at $206 \pm 24 \mathrm{nmol}$ of $\mathrm{H}_{2} \mathrm{~S}$ produced during $1 \mathrm{~min}$ per $1 \mathrm{mg}$ of protein for the control, and $38 \pm 17 \mathrm{nmol}$ of $\mathrm{H}_{2} \mathrm{~S}$ produced during $1 \mathrm{~min}$ per $1 \mathrm{mg}$ of protein for the sham group. It can be concluded that the decreased $\mathrm{H}_{2} \mathrm{~S}$ production was associated with a significant decrease in the activity and expression of enzymes responsible for its production, especially MPST and CTH. In addition to changes caused by the stress (surgery, anesthesia and analgesia), the inflammatory process and other changes in AP resulted in rapid turnover of $\mathrm{H}_{2} \mathrm{~S}$ and no net production, although MPST expression was significantly higher in comparison to the sham group. Although recent studies have demonstrated that $\mathrm{H}_{2} \mathrm{~S}$ plays a key role in inflammation, the cellular source of $\mathrm{H}_{2} \mathrm{~S}$ and the mechanism by which $\mathrm{H}_{2} \mathrm{~S}$ acts as an inflammatory mediator in the pancreas is yet to be found (Tamizhselvi et al., 2007). Okamoto and others (Okamoto et al., 2014)

Table 3. The activity of MPST, CTH, TST, and CBS, and the sulfane sulfur level

\begin{tabular}{llllll}
\hline & MPST & CTH & TST & CBS & Sulfane sulfur \\
\hline & & $\mathrm{nmol} \cdot \mathrm{mg}^{-1} \cdot \mathrm{min}^{-1}$ & $\mathrm{pmol} \cdot \mathrm{mg}^{-1} \cdot \mathrm{min}^{-1}$ & $\mathrm{nmol} \cdot \mathrm{mg}^{-1}$ \\
\hline CONTROL & $1735 \pm 430$ & $3.73 \pm 0.36$ & $2056 \pm 660$ & $\mathrm{ND}$ & $180 \pm 50$ \\
\cline { 3 - 3 } & $984 \pm 179^{*}$ & $2.02 \pm 0.61^{*}$ & $1419 \pm 442^{*}$ & $0.67 \pm 0.01$ & $166 \pm 50$ \\
\hline AP & $432 \pm 155^{*}$ & $1.63 \pm 0.45^{*}$ & $1033 \pm 390^{*}$ & $\mathrm{ND}$ & $185 \pm 50$
\end{tabular}

Experiments were carried out in the pancreases homogenates for three experimental groups. Data represents the mean value from four independent experiments. Each value is the mean of $15-20$ repeats. AP=acute pancreatitis, ND=not detected. ${ }^{*} p<0.05 \mathrm{SHAM}, \mathrm{AP} v s$. CONTROL, ${ }^{\Delta} p<0.05$ AP vs. SHAM, Mann-Whitney test 


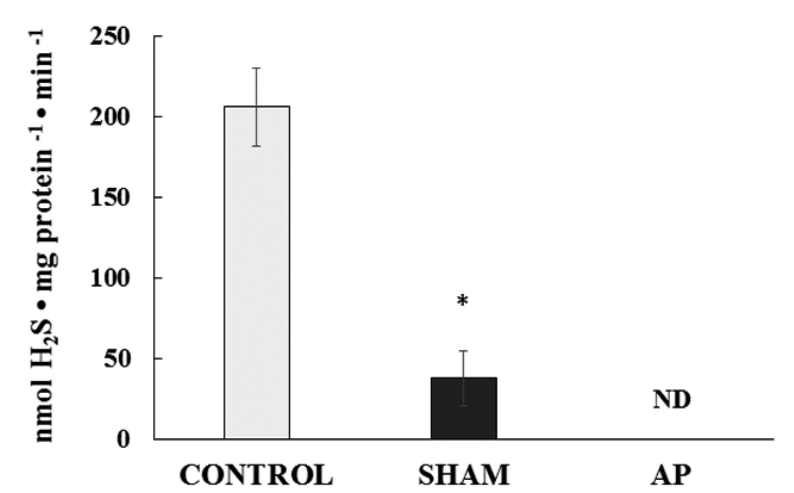

Figure 3. $\mathrm{H}_{2} \mathrm{~S}$ production

Experiments were carried out for the three experimental groups after incubation with L-cysteine as a main endogenous substrate for $\mathrm{H}_{2} \mathrm{~S}$ producing enzymes. The data represent mean value from 10-15 repeats from three independent experiments. ${ }^{*} p<0.05$ SHAM, AP vs. CONTROL, Mann-Whitney test, AP=acute pancreatitis, ND=not detected

reported that lack of CTH induces apoptotic beta-cell death and promotes development of the high-fat diet (HFD)-induced diabetes. $\mathrm{H}_{2} \mathrm{~S}$ produced by CTH is part of the homeostatic mechanism used by the pancreatic beta-cells to inhibit insulin release and to reduce the cellular stress evoked by glucose, possibly via the anti-oxidant properties of $\mathrm{H}_{2} \mathrm{~S}$.

Many scientific reports have separately confirmed expression of CTH, CBS, MPST, and TST in the mammalian pancreas (Bhatia et al., 2005; Tamizhselvi et al., 2007; Taniguchi \& Niki, 2011; Bhatia, 2012; Eskandarzade et al., 2012; Tomita et al., 2016). However, here we have confirmed for the first time the expression and activity of all four enzymes involved in $\mathrm{H}_{2} \mathrm{~S}$ production in the normal pancreas and suggested the most important role of MPST.

Table 4 shows the level of GSH, GSSG, CSH and CSSC in the pancreas of experimental groups. We observed that the level of cystathionine (Fig. 4) (substrate for CTH) and cysteine (Table 4) (substrate for MPST, CTH and CBS) were both significantly increased in acute pancreatitis, in comparison to the sham group. A decreased activity (MPST, CTH) may suggest that substrates for $\mathrm{H}_{2} \mathrm{~S}$ production have been accumulated. In addition, an increase in the level of cysteine might be associated with the pancreatic proteolysis process wherein necrotic changes have been observed (Fig. 1) (Lecker et al., 2006).

On the other hand, GSH concentration in the pancreas is one of the highest in mammals, and this tissue

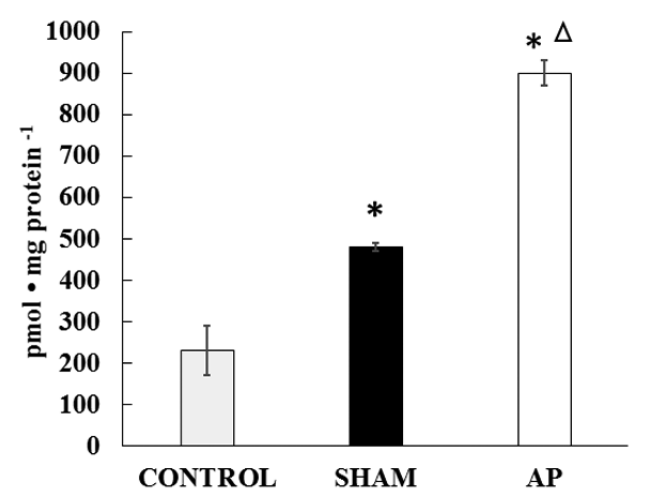

Figure 4. The level of cystathionine

Experiments were carried out for the three experimental groups using the RP-HPLC method. Data represents mean values from $15-20$ repeats. $A P=$ acute pancreatitis, ${ }^{*} p<0.05$ SHAM, AP vs. CONTROL, ${ }^{\Delta} p<0.05$ AP vs. SHAM, Mann-Whitney test

exhibits an active transsulfuration pathway and GSH synthesis, despite the relatively low activity of the glutamate cysteine ligase (GCL). GSH depletion in the pancreatic tissue is a hallmark of the initial phase of AP (Pérez et al., 2015). Total glutathione calculated as a sum of 2 GSSG content + GSH content, had significantly increased in the acute pancreatitis group and in the sham group, due to a significant increase in the level of reduced glutathione in response to stress caused by surgery, anesthesia and analgesia. The increased level of the total glutathione in AP $\left(5.14 \mathrm{nmol} \cdot \mathrm{mg}^{-1}\right)$, in comparison to the sham group $\left(3.33 \mathrm{nmol} \cdot \mathrm{mg}^{-1}\right)$, confirmed its production in this tissue. On the other hand, low GSH/ GSSG ratio indicates that the equilibrium is moved towards the oxidized form. However, Malmezat and others (Malmezat et al., 2017) reported that the glutathione concentrations were also significantly higher in the liver, spleen, kidneys and gastrocnemius muscle of septic rats, presumably in order to combat oxidative stress induced by sepsis. GSH is the major non-protein thiol in mammalian cells and plays a central role as an antioxidant. We suppose that in the case of acute pancreatitis, cysteine might be the major substrate for GSH synthesis (Table 4).

\section{CONCLUSIONS}

MPST, CTH, TST and CBS are expressed in the rat pancreas with a possibly significant role of MPST in the

Table 4. The level of reduced and oxidized glutathione, and the level of cysteine and cystine

\begin{tabular}{lccc}
\hline & GSH & GSSG & CSH \\
\hline & & & CSSC $\cdot \mathrm{mg}^{-1}$ protein \\
CONTROL & $1.37 \pm 0.26$ & $0.40 \pm 0.15$ & $4.45 \pm 1.53$ \\
SHAM & $2.71 \pm 0.68^{*}$ & $0.31 \pm 0.09$ & $21.42 \pm 6.96^{*}$ \\
\hline AP & $3.13 \pm 0.91^{*}$ & $1.01 \pm 0.20^{* \Delta}$ & $36.34 \pm 7.24^{* \Delta}$ \\
\hline
\end{tabular}

Experiments were carried out for the three experimental groups using the RP-HPLC method. The data represents mean values from 15-20 repeats. $\mathrm{AP}=$ acute pancreatitis, $\mathrm{GSH}=$ glutathione reduced, $\mathrm{GSSG}=$ glutathione oxidized, $\mathrm{CSH}=\mathrm{cysteine}, \mathrm{CSSC}=\mathrm{cystine},{ }^{*} p<0.05 \mathrm{SHAM}, \mathrm{AP}$ vs. $\mathrm{CONTROL}$, ${ }^{\Delta} p<0.05$ AP vs. SHAM, Mann-Whitney test 
$\mathrm{H}_{2} \mathrm{~S}$ production, because of its highest specific activity. Low CBS expression does not change due to stress and AP. Stress caused by the surgery, anesthesia and analgesia resulted in decreased MPST and CTH expression, and decreased MPST, CTH, and TST activity. MPST expression was significantly higher in the AP group, in comparison to the sham group. Changes observed in AP pancreas were associated with a significant increase in MPST expression, as compared to the sham group. Endogenous synthesis of $\mathrm{H}_{2} \mathrm{~S}$ decreases as a result of the surgery stress, and furthermore $\mathrm{H}_{2} \mathrm{~S}$ production was not detected in AP, which could be coupled with its higher turnover due to inflammatory state in the tissue. Much higher cysteine levels in AP could mainly result from a decreased activity of MPST and CTH, and proteolysis occurring in the damaged tissues. Our results suggest an important function for MPST in the hydrogen sulfide metabolism in acute pancreatitis.

\section{Conflicts of Interest}

The authors declare no conflict of interest.

\section{Author contributions}

T.H, M.G-K, and K.B provided the surgical procedure and experimental model. T.H provided histopathological evaluation and interpreted the results. P.B.-A. provided experimental data, analyzed data, and wrote the manuscript in consultation with M.W. M.W. discussed the results and contributed to the final manuscript.

\section{Acknowledgements}

The authors thank Professor Marcin Ufnal, PhD (Department of Physiology and Experimental Pathophysiology, Medical University of Warsaw) for significant involvement in planning all experiments and crucial contribution in discussion of the results.

P.B-A would like to thank research colleagues; Anna Bentke PhD, and Kinga Kaszuba MSC (Chair of Medical Biochemistry, Jagiellonian University, Collegium Modicum, Cracow) for help with edition of the English version of the manuscript.

\section{REFERENCES}

Batra HS, Kumar A, Saha TK, Misra P, Ambade V (2015) Comparative study of serum amylase and lipase in acute pancreatitis patients. Ind J Clin Biochem 30: 230-233. https://doi.org/10.1007/s12291-0130416-y

Bhatia M (2012) Role of hydrogen sulfide in the pathology of inflammation. Hindawi Publishing Corporation Scientifica, 12: Article ID 159680, 12 pages. https://doi.org/10.6064/2012/159680

Bhatia M, Wong FL, Fu D, Lau HY, Moochhala SM, Moore PK (2005) Role of hydrogen sulfide in acute pancreatitis and associated lung injury. FASEB J 19: 623-625. https://doi.org/10.1096/fj.04$3023 \mathrm{fje}$

Bronowicka-Adamska P, Wróbel M, Zagajewski J (2011) RP-HPLC method for quantitative determination of cystathionine, cysteine and glutathione: An application for the study of the metabolism of cysteine in human brain. J Chromatogr B 879: 2005-2009. https:// doi.org/10.1016/j.jchromb.2011.05.026

Bronowicka-Adamska P, Wróbel M, Magierowski M, Magierowska K, Kwiecień S, Brzozowski T (2017) Hydrogen sulphide production in healthy and ulcerated gastric mucosa of rats. Molecules 22: 1-12. https://doi.org/10.3390/molecules22040530

Bronowicka-Adamska P, Wróbel M, Zagajewski J (2015) An application of RP-HPLC for determination of the activity of cystathionine beta-synthase and gamma-cystathionase in tissue homogenates. $\mathrm{Ni}$ tric Oxide 46: 186-191. https://doi.org/10.1016/j.niox.2014.09.159

Collin M, Anuar FBM, Murch O, Bhatia M, Moore PK, Thiemermann Ch (2005) Inhibition of endogenous hydrogen sulfide formation reduces the organ injury caused by endotoxemia Brit J Pharmacol 146: 498-505. https://doi.org/10.1038/sj.bjp.0706367
Czubak J, Wróbel M, Jurkowska H (2002) Cystathionine $\gamma$-lyase (EC 4.4.1.1): an enzymatic assay of $\alpha$-ketobutyrate using lactate dehydrogenase. Acta Biol Cracov Ser Zool 44: 113-117. https://doi. org/10.5604/17322693.1085372

Dominik PK, Cassidy PB, Roberts JC (2001) A new and versatile method for determination of thiolamines of biological importance. J Chromatogr B 761: 1-12. https://doi.org/10.1016/s03784347(01)00298-5

Elrod JW, Calvert JW, Morrison J, Doeller JE, Kraus DW, Tao L, Jiao X, Scalia R, Kiss L, Szabo C, Kimura H, Chow CHW, Lefer DJ (2007) Hydrogen sulfide attenuates myocardial ischemia-reperfusion injury by preservation of mitochondrial function. PNAS 104: 15560-15565. https://doi.org/10.1073/pnas.0705891104

Eskandarzade N, Aminlari M, Golami S, Tavana M (2012) Rhodanese activity in different tissues of the ostrich. Br Poult Sci 53: 270-273. https://doi.org/10.1080/00071668.2012.682722

Hyun JJ, Lee HS (2014) Experimental models of pancreatitis. Clin Endosc 47: 212-216. https://doi.org/10.5946/ce.2014.47.3.212

Kabil O, Vitvitsky V, Xie P, Banerjee R (2011) The Quantitative Significance of the Transsulfuration Enzymes for $\mathrm{H}_{2} \mathrm{~S}$ Production in Murine Tissues. Antioxid Redox Signal 15: 363-372. https://doi. $\operatorname{org} / 10.1089 / \operatorname{ars} .2010 .3781$

Kang K, Zhao M, Jiang H, Tan G, Pan S, Sun X (2009) Role of hydrogen sulfide in hepatic ischemia reperfusion-induced injury in rats. Liver Transpl 15: 1306-1314. https://doi.org/10.1002/lt.21810

Kimura Y, Goto Y, Kimura H (2010) Hydrogen sulfide increases glutathione production and suppresses oxidative stress in mitochondria. Antioxid Redox Signal 12: 1-13. https://doi.org/10.1089/ ars.2008.2282

Konończuk T, Krzyżak M, Żendzian-Piotrowska M, Kurek K (2018) Epidemiology and etiology of acute pancreatitis. Med Rodz 21: 5160. https://doi.org/10.25121/MR.2018.21.2A.51

Lecker SH, Goldberg AL, Mitch WE (2006) Protein degradation by the ubiquitin-proteasome pathway in normal and disease states. J Am Soc Nephrol 17: 1807-1819. https://doi.org/10.1681/ ASN.2006010083

Libiad M, Yadav PK, Vitvitsky V, Martinov M, Banerjee R (2014) Organization of the human mitochondrial hydrogen sulfide oxidation pathway. J Biol Chem 289: 30901-30910. https://doi.org/10.1074/ ibc.M114.602664

Lowry OH, Rosenbrough NJ, Farr AL, Randall RI (1951) Protein measurement with the Folin phenol reagent. J Biol Chem 193: 265275

Malmezat T, Manohar M, Verma AK, Venkateshaiah SU, Sanders NL, Mishra A (2017) Pathogenic mechanisms of pancreatitis. World J Gastrointest Pharmacol Ther 8: 10-25. https://doi.org/10.4292/wjgpt. v8.i1.10

Matsuo Y, Greenberg DM (1958) A crystalline enzyme that cleaves homoserine and cystathionine. I Biol Chem 230: 545-560

Murphy E, Steenbergen C (2007) Preconditioning: the mitochondrial connection. Ann Rev Physiol 69: 51-67. https://doi.org/10.1146/annurev.physiol.69.031905.163645

Nagahara H (2018) Multiple role of 3-mercaptopyruvate sulfurtransferase: antioxidative function, $\mathrm{H}_{2} \mathrm{~S}$ and polysulfide production and possible $\mathrm{SO}_{\mathrm{x}}$ production. $\mathrm{Br} J$ Pharmacol 175: 577-589. https://doi. org/10.1111/bph.14100

Okamoto M, Ishizaki T, Kimura T (2015) Protective effect of hydrogen sulfide on pancreatic beta-cells. Nitric Oxide 30: 32-36. https:// doi: 10.1016/j.niox.2014.11.007

Pérez S, Pereda J, Sabater L, Sastre J (2015) Redox signaling in acute pancreatitis. Redox Biol 5: 1-14. https://doi.org/10.1016/j.redox.2015.01.014

Qu Z, JiangY, Wu BQ, Duan YF, Sun ZD, Luo GH (2014) Cystathionine-gamma-lyase inhibitor attenuates acute lung injury induced by acute pancreatitis in rats. Arch Med Sci 29: 825-829. https://doi. org/10.5114/aoms.2014.44873

Sörbo B (1955) Rhodanese. Methods Ensymol 2: 334-337. https://doi. org/10.1016/S0076-6879(55)02207-6

Sodha NR, Clements RT, Feng J, Liu Y, Bianchi C, Horvath EM, Szabo C, Stahl GL, Sellke FW (2009) Hydrogen sulfide therapy attenuates the inflammatory response in a porcine model of myocardial ischemia/reperfusion injury. J Thoracic Cardiovasc Surgery 138: 977-984. https://doi.org/10.1016/j.jtcvs.2008.08.074

Stein A, Bailey SM (2013) Redox biology of hydrogen sulfide: Implications for physiology, pathophysiology, and pharmacology. Redox Biol 1: 32-39. https://doi.org/10.1016/j.redox.2012.11.006

Stipanuk MH, Beck PW (1982) Characterization of the enzymatic capacity for cysteine desulphydration in the liver and kidney of the rat. Biochem J 206: 267-277. https://doi.org/10.1042/bj2060267

Stipanuk MH, Ueki I (2011) Dealing with methionine/homocysteine sulfur: cysteine metabolism to taurine and inorganic sulfur. I Inherit Metab Dis 34: 17-32. https://doi.org/10.1007/s10545-009-90

Tamizhselvi R, Moore PK, Bhatia M (2007) Hydrogen sulfide acts as a mediator of inflammation in acute pancreatitis: in vitro studies using isolated mouse pancreatic acinar cells. J Cell Mol Med 11: 315-326. https://doi.org/10.1111/j.1582-4934.2007.00024.x 
Taniguchi S, Niki I (2011) Significance of hydrogen sulfide production in the pancreatic $\beta$-cell. J Pharmacol Sci 116: 1-5. https://doi. org/10.1254/jphs.11r01cp

Tomita M, Nagahara N, Ito T (2016) Expression of 3-mercaptopyruvate sulfurtransferase in the mouse. Molecules 11: 1-8. https://doi. org/10.3390/molecules21121707

Valentine WN, Frankelfeld JK (1974) 3-Mercaptopyuruvate sulfurtransferase (EC 2.8.1.2): A simple assay adapted to human blood cells. Clin Chim Acta 14: 205-210. https://doi.org/10.1016/00098981(74)90031-x

Wood L (1987) Sulfane sulfur. Methods Ensymol 143: 25-29. https:// doi.org/10.1016/0076-6879(87)43009-7
Wróbel M, Jurkowska H, Śliwa L, Srebro Z (2004) Sulfurtransferases and cyanide detoxification in mouse liver, kidney, and brain. Toxicol Mech Methods 14: 331-337. https://doi. org/10.1080/15376520490434683

Yang W, Yang G, Jia X, Wu L, Wang R (2005) Activation of $\mathrm{K}_{\text {AT }}$ channels by $\mathrm{H}_{2} \mathrm{~S}$ in rat insulin-secreting cells and the underlying mechanisms. I Physiol 569: 519-531. https://doi.org/10.1113/jphysiol.2005.097642

Zanardo RCO, Brancaleone V, Distrutti E, Fiorucci S, Cirino G, Wallace JL (2006) Hydrogen sulfide is an endogenous modulator of leukocyte-mediated inflammation. FASEB J 20: 2118-2120. https:/ / doi.org/10.1096/fj.06-6270fje 